\title{
Analytical quality by design approach to RP-HPLC method development and validation for simultaneous estimation of esomeprazole and naproxen in modified-release dosage form
}

\author{
Khandokar Farjana Urmi ${ }^{1,2}$, Md. Saddam Nawaz ${ }^{2^{*}}$ and S. M. Ashraful Islam
}

\begin{abstract}
Background: The present work describes the development and validation of a new, specific, accurate, and precise stability-indicating RP-HPLC method for the simultaneous estimation of Esomeprazole (ESP) and Naproxen (NAP) in modified-release bi-layer tablet dosage form. Analytical Quality by Design concept was implemented through the method development exercise to establish the robustness of the method.

Results: Method development was performed on C18, $250 \times 4.6 \mathrm{~mm} \mathrm{ID}$, and $5 \mu \mathrm{m}$ particle size column with $10 \mu \mathrm{l}$ injection volume using a photodiode array (PDA) detector to monitor the detection at $280 \mathrm{~nm}$. The mobile phase consisted of the buffer: methanol at a ratio of $50: 50(\mathrm{v} / \mathrm{v})$, and the flow rate was maintained at $1.5 \mathrm{ml} / \mathrm{min}$, and the column oven temperature was maintained at $30^{\circ} \mathrm{C}$. The retention times for NAP and ESP were found $5.9 \pm 0.1$ and $8.9 \pm 0.1 \mathrm{~min}$, respectively. The method was validated in terms of system suitability, specificity, accuracy, linearity, precision, and solution stability. Linearity was observed over the range of concentration $8-12 \mu \mathrm{g} / \mathrm{ml}$ for ESP and 200-300 $\mathrm{\mu g} / \mathrm{ml}$ for NAP, and the correlation coefficient $\left(R^{2}\right)$ was found excellent $>0.999$. The method was specific to ESP and NAP, and the peak purity was found $99.97 \%$ for ESP and $100.00 \%$ for NAP. The method was precise and had \%RSD less than 2. Recovery study for accuracy with placebo was found in the range of $99.63-100.36 \%$ for ESP and 99.91-100.43\% for NAP.
\end{abstract}

Conclusion: This proposed fast, reliable, cost-effective method can be used as a quality control tool for the simultaneous determination of Esomeprazole and Naproxen in routine laboratory analysis.

Keywords: RP-HPLC, Analytical quality by design, Esomeprazole, Naproxen, Modified-release (MR) tablet

\footnotetext{
*Correspondence: nawazdu@gmail.com

${ }^{2}$ Quality Assurance Department, ACI HealthCare Limited, Treepordi,

Sonargaon, Narayanganj 1440, Bangladesh

Full list of author information is available at the end of the article
} 


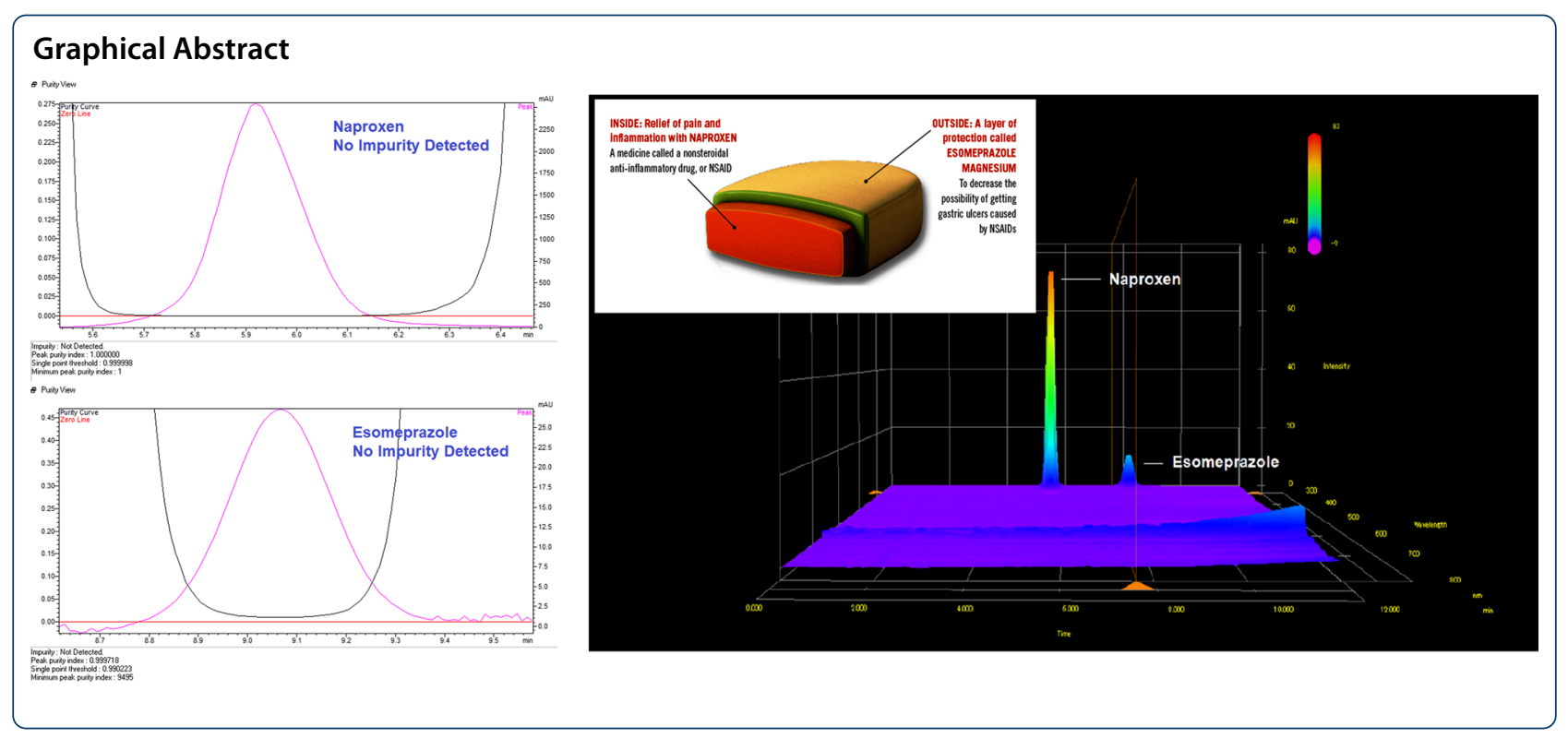

\section{Background}

In the pharmaceutical industry, Quality by Design (QbD) is a modern approach to quality. Product and manufacturing process quality are the goals of pharmaceutical development $[1,2]$. The quality issue in pharmaceutical industries has become a serious and pivotal topic among the countries that received warning letters and import alerts from the US FDA. Serious measures have been taken by pharmaceutical companies across the world to put more quality control measures in place. The manufacturing of pharmaceutical products used for achieving desired therapeutic aids for the treatment of diverse ailments is considered highly regulated for the past few decades. Poor manufacturing standards and their quality is being a worry for the industries and the regulatory agencies despite the continuous contribution by the pharmaceutical industries in new drug discovery and innovations [3]. Joseph M. Juran, who is the world's wellknown expert in quality control, has extended the philosophies of quality from the ancient conventional statistical practice to modern quality management [4]. Juran is the man behind the quality of Japanese, suggests the need for managerial processes that focus on quality. The three managerial processes explained by Juran comprises of quality planning, quality control, and quality improvement, these three processes are combined called Juran's Trilogy [5]. Juran invented the term "quality by design" in his well-known publication "Juran on Quality by Design." Juran believed that quality could be strategic and that most quality problems were related to the way quality was strategized $[6,7]$.

ICH Q8 guidance mentions QbD, stating that "Quality cannot be tested into products, i.e., quality should be built in by design" (Quality by Design) [8]. QbD is defined in ICH Q8 as a systematic approach to drug development that begins with set of objectives and emphasizes product knowledge, process control, and quality risk management approaches. Equivalent to process $\mathrm{QbD}$, the outcome of Analytical Quality by Design (AQbD) is well understood and fit for the intended purpose with robustness throughout the lifecycle.

AQbD has different aspects such as Analytical Target Profile (ATP), Risk assessment, Screening design, Method Optimization, Design of Experiments (DoE), Design space or Method Operable Design Region (MODR), Method Validation and Continuous Method Monitoring, etc. [9]. Analytical researchers have even less experience with or familiarity to the AQbD methodology for analytical methods yet, if any. As a result, many individuals believed that $\mathrm{AQbD}$ was implemented by including DoE in the analytical approach, which is inaccurate and misleading [10]. As a result of the preceding discussion, analytical method development using the QbD approach is a recent area of focus that must be enforced. Similar to product $\mathrm{QbD}$, the process of developing and validating analytical methods helps the product's quality even more, with a high degree of confidence, and it may be similarly profited. The dependence of pharmaceutical development and manufacture on robust analytical data intensifies the need for rigor in analytical method development and increasingly an AQbD [11-14].

Esomeprazole Magnesium Trihydrate (ESP), bis(5methoxy-2-[(S)-[(4-methoxy-3,5-dimethyl-2-pyridinyl) methyl] sulfinyl]-1-H-benzimidazole-1-yl)magnesium trihydrate (Fig. 1), is a compound that inhibits gastric acid secretion. ESP is the S-isomer of omeprazole, the 


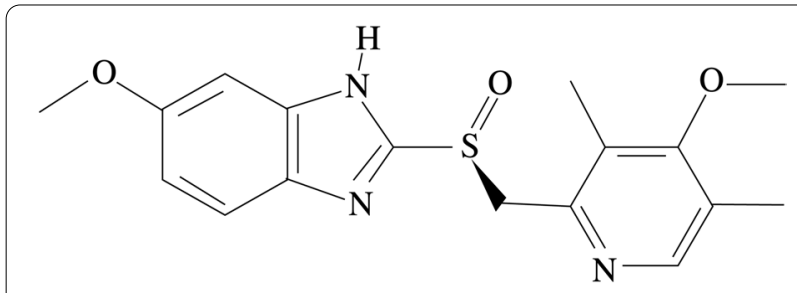

Fig. 1 Chemical structure of esomeprazole

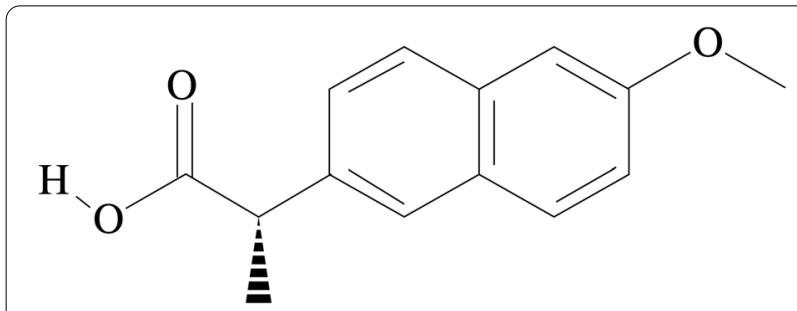

Fig. 2 Chemical structure of naproxen

first single optical isomer proton pump inhibitor, which provides better acid control than conventional racemic proton pump inhibitors [15]. Esomeprazole reduces stomach acid secretion through inhibition of the $\mathrm{H}^{+}$/ $\mathrm{K}^{+}$-ATPase in the parietal cells of the stomach [16]. By inhibiting the functioning of this transporter, the drug prevents the formation of stomach acid. It is cost-effective in the treatment of dyspepsia, peptic ulcer disease, gastroesophageal reflux disease, and Zollinger-Ellison syndrome.

Naproxen (NAP) is a chemical, (S)-6-methoxy- $\alpha$ methyl-2-naphthaleneacetic acid (Fig. 2) is a non-steroidal anti-inflammatory drug (NSAID) used to treat moderate to severe pain as well as fever, inflammation, and stiffness. It works by inhibiting both the Cyclooxygenase-1 (COX-1) and Cyclooxygenase-2 (COX-2) enzymes. Like other NSAIDs, NAP can produce disturbances in the gastrointestinal tract [17]. Because of its low risk, it is the preferred NSAID for long-term use in people at high risk of cardiovascular (for example, heart attacks or strokes) complications.

Over the past few decades, numerous approaches were taken to improve the analytical process of ESP [18-24] and NAP [25-39] using various methods like Ultra-Violet (UV) spectrophotometry, High-Performance Liquid Chromatography (HPLC), Ultra Performance Liquid Chromatography (UPLC), and Liquid chromatographymass spectrometry (LC-MS). These approaches mainly aimed to develop simple, precise, accurate, reproducible, and highly sensitive analytical techniques for the determination of ESP and NAP. Also, few types of research have been conducted for the simultaneous estimation of ESP and NAP from pharmaceutical dosage form [40-44].

A careful literature survey did not reveal any single reversed-phase high-performance liquid chromatography (RP-HPLC) analytical method for the determination of ESP and NAP simultaneously from a bi-layer modified-release (MR) tablet dosage form. In contrast to published methods, in our method, the sample preparation process was developed judgmentally that to avoid zero degradation of ESP in presence of NAP in the solution state. Therefore, the $\mathrm{pH}$ of the sample solution and the diluting solution was optimized to get the actual potency of ESP in presence of acidic NAP. In addition, published methods have some technical hitches like not stabilityindicating, organic phase ratio was higher in the mobile phase, the flow rate was high, and the peak resolution of ESP and NAP were too low. Keeping all these points into consideration, we have undertaken the present investigation with the aim to develop a stability-indicating HPLC method based on the AQbD approach for the simultaneous estimation of ESP and NAP in a combined modified-release (MR) tablet dosage form. The method was validated as per ICH Q2(R1) guidelines [45].

\section{Methods}

\section{Chemicals and reagents}

The working standard of Esomeprazole Magnesium Trihydrate (ESP) was obtained from Zhejiang Tianxin Pharma. Co. Ltd., China, and Naproxen (NAP) were obtained from Metrochem API Private Ltd., India having purity $98.78 \% \mathrm{w} / \mathrm{w}$ and $99.72 \% \mathrm{w} / \mathrm{w}$ respectively. Acetonitrile (ACN) HPLC grade (Scharlau, Spain), Methanol (MeOH) HPLC grade (Scharlau, Spain), Sodium Hydroxide pellets Analytical Reagent (AR) grade (Scharlau, Spain), Disodium Hydrogen Phosphate AR grade (Scharlau, Spain), Sodium Dihydrogen Phosphate AR grade (Scharlau, Spain), Trisodium Hydrogen Phosphate AR grade (Scharlau, Spain), Phosphoric Acid AR grade (Merck; Germany) and Hydrochloric Acid (Scharlau, Spain) were used for analytical purposes. HPLC grade water was obtained through a Millipore water purification system (Model- Arium 611DI, Sartorious).

Vimovo ${ }^{\circledR}$ modified-release (MR) tablet, a Reference Listed Drug (RLD) product that contains enteric-coated (gastro-resistant) $500 \mathrm{mg}$ naproxen (NAP) and filmcoated $20 \mathrm{mg}$ esomeprazole (ESP). Vimovo ${ }^{\circledR}$ itself is not available in Bangladesh; however, a generic form of Vimovo ${ }^{\circledR}$ is manufactured in Bangladesh. Laboratory prepared bi-layer tablets were used in this study, and its formulation was gifted by ACI limited, Bangladesh, commercial name Anaflex Max DR 500/20 (Fig. 3). 


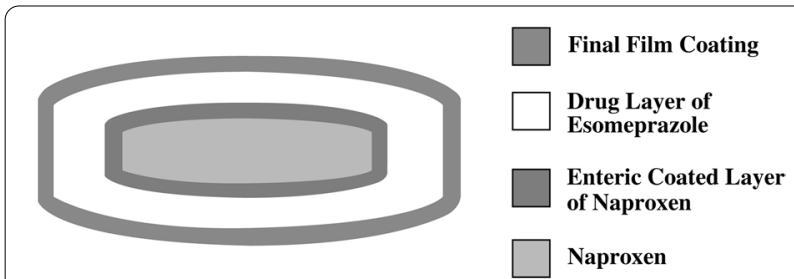

Fig. 3 Anaflex max DR 500/20 tablet

\section{HPLC instrumentation and chromatographic conditions}

Chromatographic separation was achieved by using Prominence LC-20AD High-Performance Liquid Chromatography (Shimadzu, Japan), equipped with degasser DGU-20A 5, variable wavelength programmable photodiode array (PDA) detector SPD-M20A, autosampler SIL-20 AC HT, and column oven CTO-10 AS VP. The data was recorded using LC LabSolution software (Shimadzu, Japan). Other laboratory instruments such as $\mathrm{pH}$ meter (Jenway 3510, UK), electronic weighing balance (Boeco, Germany), and ultrasonic bath (Clifton, UK) were also used. Dionex ultimate 3000 series (USA) HPLC and Chromeleon software (USA) was used during reproducibility under precision study.

\section{Chromatographic conditions}

ProntoSIL SC, $\mathrm{C}_{18}$-ace-EPS, $250 \times 4.6 \mathrm{~mm}$ ID, and $5 \mu \mathrm{m}$ particle size column (Bischoff, Germany) were used as the stationary phase. The column oven temperature was kept at $30{ }^{\circ} \mathrm{C}$, and the mobile phase flow rate was maintained at $1.5 \mathrm{ml} / \mathrm{min}$. The detection was monitored at $280 \mathrm{~nm}$. The injection volume was $10 \mu \mathrm{l}$, and the retention time was $5.9 \pm 0.1$ and $8.9 \pm 0.1 \mathrm{~min}$ for NAP and ESP, respectively.

\section{Preparation of mobile phase}

Preparation of phosphate buffer of $\mathrm{pH}$ 6.8:

Solution A: $31.20 \mathrm{~g}$ of Sodium Dihydrogen Phosphate Dihydrate was weighed and dissolved in $1000 \mathrm{ml}$ of HPLC grade water. Solution B: $35.63 \mathrm{~g}$ of Disodium Hydrogen Phosphate Dihydrate was weighed and dissolved in $1000 \mathrm{ml}$ of ultra-pure HPLC grade water.

$255 \mathrm{ml}$ of solution $A$ and $245 \mathrm{ml}$ of solution $B$ were mixed well and dilute with HPLC water to $900 \mathrm{ml}$ to prepare buffer solution for the mobile phase. Then the resultant solution mixture was adjusted to $\mathrm{pH} 6.80 \pm 0.01$ with $1 \mathrm{M}$ Sodium Hydroxide and volume up to $1000 \mathrm{ml}$ with HPLC grade water.

Mobile phase: Finally, a mixture of the above-prepared buffer and $\mathrm{MeOH}$ at a ratio of 50: $50(\% \mathrm{v} / \mathrm{v})$ was used as the mobile phase. The prepared buffer and $\mathrm{MeOH}$ were filtered using $0.2 \mu \mathrm{m}$ membrane filters and sonicated for 10 min using an ultrasonic bath before use.

\section{Diluting solution}

Diluent $A: 2.0 \mathrm{~g}$ of sodium hydroxide pellets were weighed accurately and dissolved in $1000 \mathrm{ml}$ of ultrapure water.

Diluent $B: 19.0 \mathrm{~g}$ of trisodium hydrogen phosphate dodecahydrate was weighed accurately and dissolved into $900 \mathrm{ml}$ of ultra-pure water. Then the $\mathrm{pH}$ was adjusted to $11.0 \pm 0.01$ with $1 \mathrm{M}$ orthophosphoric acid, and the volume was made up to $1000 \mathrm{ml}$ with water.

\section{Preparation of standard solution}

Step I: Preparation of standard stock solution

$10.0 \mathrm{mg}$ ESP working standard was accurately weighed and transferred into a clean, and dry $100 \mathrm{ml}$ volumetric flask, and $10 \mathrm{ml}$ of $\mathrm{MeOH}$ was added to dissolve the ESP. Subsequently, $40 \mathrm{ml}$ of diluents $A$ was added to the solution. After that $250.0 \mathrm{mg}$ NAP working standard was accurately weighed and transferred into that volumetric flask, and the volume was adjusted up to the mark with ultra-pure water. This solution was sonicated for $10 \mathrm{~min}$. The concentration of ESP and NAP in this solution were found $100 \mu \mathrm{g} / \mathrm{ml}$ and $2500 \mu \mathrm{g} / \mathrm{ml}$ respectively.

Step II: Preparation of final standard solution

$5 \mathrm{ml}$ aliquot form of the final solution of step I was transferred into another dry $50 \mathrm{ml}$ standard volumetric flask and diluted to the mark with the diluent $B$. Finally, the solution was filtered through a $0.45 \mu \mathrm{m}$ polytetrafluoroethylene (PTFE) disk filter and transferred to the amber vial. The final concentration of ESP and NAP were $10 \mu \mathrm{g} / \mathrm{ml}$ and $250 \mu \mathrm{g} / \mathrm{ml}$, respectively.

\section{Sample preparation}

Step I: Preparation of sample stock solution

Five (5) tablets (equal to $100 \mathrm{mg}$ of ESP and $2500 \mathrm{mg}$ of NAP) were weighed and transferred into a clean and dry $1000 \mathrm{ml}$ standard volumetric flask and $100 \mathrm{ml}$ of $\mathrm{MeOH}$ was added. Gentle shaking was done for 3-5 min to dissolve the outermost ESP layer. Next, $400 \mathrm{ml}$ of diluents $A$ was added to the volumetric flask and dissolved the tablet by shaking at $250 \mathrm{rpm}$ for $15 \mathrm{~min}$ in a shaker. After that $400 \mathrm{ml}$ of diluents $A$ was added to that volumetric flask. The volume was adjusted up to the mark with ultra-pure HPLC water. That solution was sonicated for $10 \mathrm{~min}$ and filtered through Whatman filter paper 1. Concentrations 
of ESP and NAP in this stock solution were $100 \mu \mathrm{g} / \mathrm{ml}$ and $2500 \mu \mathrm{g} / \mathrm{ml}$.

Step II: Preparation of final sample solution

$5 \mathrm{ml}$ aliquot form of the final solution of step I was transferred into another dry $50 \mathrm{ml}$ volumetric flask and diluted to the mark with the diluent $B$. The final concentration of ESP and NAP were $10 \mu \mathrm{g} / \mathrm{ml}$ and $250 \mu \mathrm{g} / \mathrm{ml}$, respectively. Finally, the solution was filtered through a $0.45 \mu \mathrm{m}$ PTFE disk filter and transferred to the amber vial.

\section{Method development}

AQbD method development involves evaluation and optimization of the various stages of sample preparation, chromatographic separation, detection, and quantification, including the application of Quality Risk Assessment (QRA) and various QRA tools. The ultimate target of QRA on AQbD was to achieve a science and risk-based process of a method that would be precise, selective, as well as sensitive and can separate all the chromatograms other than Active Pharmaceutical Ingredients (APIs) and all the degradation from the analyte of the sample. To understand the Critical Method Parameters (CMPs), Critical Material Attributes (CMAs), and their best-fit approach through the development process, QRA tools: such as Ishikawa/fishbone diagram (cause and effect), design of experiments (DoE), were adopted.

The potential variables that can affect method quality were identified using an Ishikawa/fishbone diagram (Fig. 4). After defining the method variables, conventional experimental designs such as statistical DoE were applied to the selected method variables leading to process and method understanding. The DoE helps eliminate the need for performing many runs and achieves desirable results from a limited number of experiments. DoE was also applied to understand the best possible optimization relation between input variables and output responses of the method. Table 1 illustrates the experimental data of factors and their corresponding responses.

Besides, prior experiences of method development also applied in the screening process of method variables for optimization, such as solvent optimization. The quality of any HPLC method depends on the proper selection of diluents, stationary and mobile phases which relies on the Physico-chemical properties of the sample and its solubility. The eminent challenge of this method development study is the stability of ESP in solution state with acidic NAP, due to Proton Pump Inhibitor's (PPI) common acid-labile nature, like most other PPIs, ESP's rate of degradation increases with decreasing of $\mathrm{pH}$ [46]. Therefore, solvents/diluents optimization is designed in a way that can prevent the degradation of ESP in the presence of acidic NAP.

\section{Method validation parameters}

The present study was conducted to obtain a new, affordable, cost-effective, and convenient method for HPLC determination of ESP and NAP in modified-release tablet dosage form. Once the chromatographic and the experimental conditions were established, the method was validated by the determination of the following parameters: system suitability, selectivity, linearity, accuracy, precision, solution stability, and forced degradation.

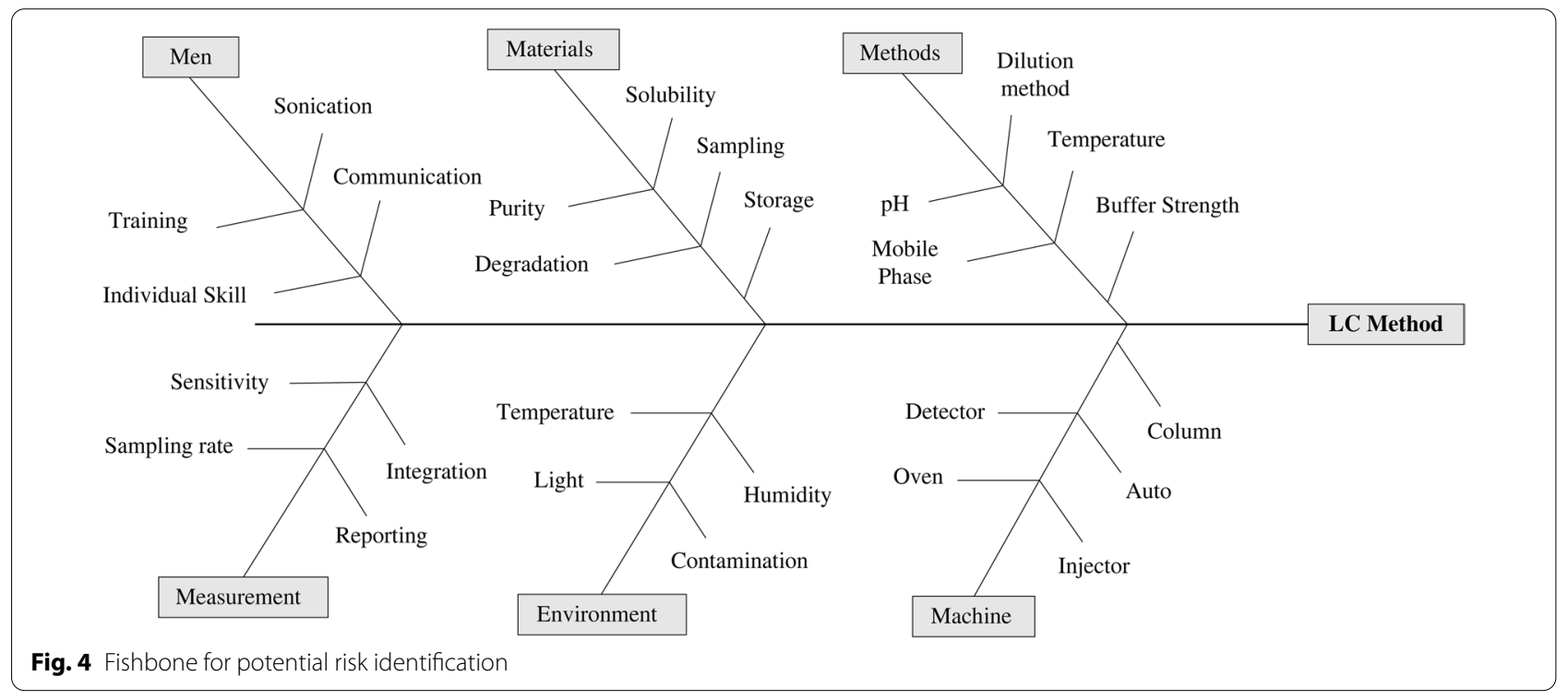


Table 1 DoE experiment for method optimization

\begin{tabular}{|c|c|c|c|c|c|c|}
\hline \multicolumn{4}{|l|}{ Factors } & \multicolumn{3}{|l|}{ Responses } \\
\hline Wavelength & $\begin{array}{l}\text { pH of phosphate } \\
\text { buffer }\end{array}$ & Flow & $\begin{array}{l}\text { Organic ratio } \\
(\mathrm{MeOH})\end{array}$ & $\begin{array}{l}\text { Retention time } \\
\text { (NAP) }\end{array}$ & $\begin{array}{l}\text { Retention time } \\
\text { (ESP) }\end{array}$ & $\begin{array}{l}\text { Tailing } \\
\text { factor } \\
\text { (NAP) }\end{array}$ \\
\hline \multirow[t]{4}{*}{254} & 7 & 0.5 & 40 & 44.5 & 63.4 & 1.37 \\
\hline & 6 & 0.5 & & 45.9 & 65.1 & 1.41 \\
\hline & 7 & 1.5 & & 12.9 & 23.5 & 1.24 \\
\hline & 6 & 1.5 & & 14.1 & 24.3 & 1.31 \\
\hline \multirow[t]{4}{*}{300} & 7 & 0.5 & & 44.5 & 63.4 & 1.39 \\
\hline & 6 & 0.5 & & 45.9 & 65.1 & 1.46 \\
\hline & 7 & 1.5 & & 12.9 & 23.5 & 1.29 \\
\hline & 6 & 1.5 & & 14.1 & 24.3 & 1.38 \\
\hline \multirow[t]{4}{*}{254} & 7 & 0.5 & 50 & 11.5 & 21.0 & 1.20 \\
\hline & 6 & 0.5 & & 11.9 & 22.9 & 0.98 \\
\hline & 6 & 1.5 & & 5.9 & 8.8 & 0.99 \\
\hline & 7 & 1.5 & & 6.1 & 9.1 & 1.28 \\
\hline \multirow[t]{4}{*}{300} & 7 & 0.5 & & 11.5 & 21.0 & 1.31 \\
\hline & 6 & 0.5 & & 11.9 & 22.9 & 1.10 \\
\hline & 6 & 1.5 & & 5.9 & 8.8 & 0.90 \\
\hline & 7 & 1.5 & & 6.1 & 9.1 & 1.25 \\
\hline
\end{tabular}

\section{System suitability}

To assess system suitability of the method, the repeatability, theoretical plates, tailing factor, capacity factor and retention time of six replicate injections of standard ESP and NAP of concentrations $10 \mu \mathrm{g} / \mathrm{ml}$ and $250 \mu \mathrm{g} /$ $\mathrm{ml}$, respectively, were used, and the appropriate recommended values were calculated.

\section{Specificity}

The specificity of the method was evaluated to ensure that there is no interference of excipients, diluting solution in the chromatogram of ESP and NAP. The specificity was studied by injecting the placebo (including Vimovo ${ }^{\circledR}$ MR Tablet), diluting solution, and standard solution of ESP and NAP.

\section{Forced degradation}

Forced degradation studies were carried out to indicate the stability-indicating property and specificity of the proposed method. Intentional degradation was attempted to stress conditions like water hydrolysis, acid hydrolysis, oxidative degradation (using 3.0\% $\mathrm{H}_{2} \mathrm{O}_{2}$ ), and thermal degradation $\left(40{ }^{\circ} \mathrm{C}\right.$ and $60{ }^{\circ} \mathrm{C}$ ) to evaluate the ability of the proposed method to separate degradation products from active ingredients.

Hydrolytic conditions Water induced degradation: $1 \mathrm{ml}$ of standard stock solution was taken from step I, mentioned earlier in "Preparation of standard solution" sec- tion and transferred to $50 \mathrm{ml}$ volumetric flasks for different conditions. Afterward, $1 \mathrm{ml}$ of ultra-pure water was added to the volumetric flask. This experiment was subjected to the conditions specified in Table 2, and the sample was collected, respectively. Later, they were diluted according to step II and analyzed.

Acid-induced degradation: $1 \mathrm{ml}$ of standard stock solution was taken from step I, mentioned earlier in "Preparation of standard solution" section, and transferred to $50 \mathrm{ml}$ volumetric flasks for different conditions. Afterward, $1 \mathrm{ml} 0.001 \mathrm{~N}$ and $0.01 \mathrm{~N} \mathrm{HCl}$ were added to the

Table 2 Thermal, photolytic, and oxidative stress testing plan for ESP and NAP

\begin{tabular}{|c|c|c|c|}
\hline Stress condition & Temp/RH & State & $\begin{array}{l}\text { Duration } \\
\text { (days) }\end{array}$ \\
\hline \multicolumn{4}{|l|}{ Hydrolytic } \\
\hline \multirow[t]{3}{*}{ Liquid state } & $25^{\circ} \mathrm{C}, 40^{\circ} \mathrm{C}$ & $0.001 \mathrm{~N} \mathrm{HCl}(\mathrm{API})$ & 7 \\
\hline & $25^{\circ} \mathrm{C}, 40^{\circ} \mathrm{C}$ & $0.01 \mathrm{~N} \mathrm{HCl}(\mathrm{API})$ & 7 \\
\hline & $25^{\circ} \mathrm{C}, 40^{\circ} \mathrm{C}$ & Water (API) & 7 \\
\hline \multicolumn{4}{|l|}{ Oxidative } \\
\hline Liquid state & $5^{\circ} \mathrm{C}, 25^{\circ} \mathrm{C}, 40^{\circ} \mathrm{C}$ & $3 \% \mathrm{H}_{2} \mathrm{O}_{2}(\mathrm{API})$ & 7 \\
\hline \multicolumn{4}{|l|}{ Thermal } \\
\hline Solid state (a) & $60^{\circ} \mathrm{C}$ & API & 7 \\
\hline Solid state (d) & $60^{\circ} \mathrm{C}$ & API+Placebo & 7 \\
\hline Solid state (c) & $40^{\circ} \mathrm{C}, 75 \% \mathrm{RH}$ & API & 7 \\
\hline Solid state (d) & $40^{\circ} \mathrm{C}, 75 \% \mathrm{RH}$ & API+Placebo & 7 \\
\hline
\end{tabular}


volumetric flasks. This experiment was subjected to the conditions specified in Table 2, and the sample was collected, respectively. Later, they were diluted according to step II and analyzed.

Oxidizing conditions Hydrogen peroxide-induced degradation: $1 \mathrm{ml}$ of standard stock solution was taken from step I, mentioned earlier in "Preparation of standard solution" section, and transferred to $50 \mathrm{ml}$ volumetric flasks for different conditions. Afterward, $1 \mathrm{ml}$ of $3 \% \mathrm{H}_{2} \mathrm{O}_{2}$ was added to the volumetric flask. This experiment was subjected to the conditions specified in Table 2 , and the sample was collected, respectively. Later, they were diluted according to step II and analyzed.

Thermal degradation Dry heat and moist heat-induced degradation: API with placebo and without placebo was subjected to the conditions indicated in Table 2. The sample was collected according to the time interval mentioned in Table 2.

\section{Accuracy with placebo}

Accuracy with placebo was determined by the recovery test, which consisted of adding and dissolving known amounts of ESP and NAP with the commercial standard of placebo. This test was conducted by three different concentrations $(80,100$, and $120 \%)$ of the test sample in three replicate sample preparations $(8,10,12 \mu \mathrm{g} / \mathrm{ml}$ and $200,250,300 \mu \mathrm{g} / \mathrm{ml}$ for ESP and NAP respectively), and the percent recoveries of ESP and NAP in drug-matrix form were calculated. The accuracy was also evaluated by linear regression analysis and computed.

\section{Linearity}

Three replicates of five different concentrations samples were prepared at $80 \%, 90 \%, 100 \%, 110 \%$, and $120 \%$ $(8,9,10,11,12 \mu \mathrm{g} / \mathrm{ml}$ and $200,225,250,275,300 \mu \mathrm{g} / \mathrm{ml}$ for ESP and NAP respectively). One injection was performed from each of these samples. The average area of each concentration was considered during the regression analysis. The analyte concentration versus the peak area was plotted. The linearity was evaluated by calculating the linear regression analysis, the square correlation coefficient $\left(R^{2}\right)$, and $\% y$-intercept using Minitab 17.

\section{Precision}

Repeatability Three replicates of three different concentrations samples were prepared at $80 \%, 100 \%$, and $120 \%$ $(8,10,12 \mu \mathrm{g} / \mathrm{ml}$ and $200,250,300 \mu \mathrm{g} / \mathrm{ml}$ for ESP and NAP respectively) to evaluate repeatability. The percent relative standard deviations (\%RSD) were calculated for area and retention time.
Intermediate precision Intermediate precision expresses within-laboratory variations: different days, different analysts, or equipment, etc. Intermediate precision is usually demonstrated by repeated measurements of the sample used in the repeatability experiment within the same laboratory. To determine the intermediate precision three replicates of three different concentrations samples were prepared at $80 \%, 100 \%$, and $120 \%(8,10,12 \mu \mathrm{g} / \mathrm{ml}$ and 200 , $250,300 \mu \mathrm{g} / \mathrm{ml}$ for ESP and NAP respectively) and analyzed on two different days and by two different analysts to evaluate day-to-day and analyst-to-analyst variations. The \%RSD values of area and retention time for intra-day (data taken from repeatability study) and inter-day were calculated for each concentration.

Reproducibility Six replicate samples at nominal concentrations were prepared $(10 \mu \mathrm{g} / \mathrm{ml}$ and $250 \mu \mathrm{g} / \mathrm{ml}$ for ESP and NAP, respectively) to evaluate reproducibility. Six injections were performed from six samples in different HPLC (dionex) and different lab, and the \%RSD was calculated for area and retention time.

\section{Solution stability}

The stability of analytical solutions was established by injecting the standard solution and sample solution at different time intervals up to $36 \mathrm{~h}(0,12,24$ and $36 \mathrm{~h})$ by keeping the autosampler temperature at room temperature $\left(25^{\circ} \mathrm{C}\right)$. The response of standard solution and sample solution was measured, and \% differences in peak area were calculated.

\section{Robustness}

Few method parameters were deliberately varied to assess the robustness of the current approach. The parameters included a variation of elution ratio of organic, flow rate, and temperature. Each of the three examined factors (organic ratio, flow rate, and temperature) was changed one at a time to estimate the effect. Replicate injections $(n=6)$ of sample solution of nominal concentration were performed under specified changes of chromatographic parameters (factors).

\section{Sensitivity}

For sensitivity study, the Detection limit (DL) and Quantitation limit (QL) was estimated by determination of signal-noise ratios of 3:1 and 10:1, respectively, by injecting series of diluted solution with known concentration.

\section{Results}

\section{Method optimization}

After selecting the proper diluents or solvents, preliminary trials were carried out with a mobile phase consisting of phosphate buffer and $\mathrm{MeOH}$ or $\mathrm{ACN}$. The pKa 
value for ESP and NAP is -4.78 and 4.15 , respectively. Buffers for the mobile phase were selected at higher $\mathrm{pH}(>\mathrm{pKa})$ as well as considering the stability of ESP to achieve good-retained peaks. $\mathrm{ACN}$ and $\mathrm{MeOH}$ (Organic solvents) were studied in various ratios with different $\mathrm{pH}$ of Sodium Phosphate buffer. Initially, the Sodium Phosphate buffer of $\mathrm{pH} 7.0$ was analyzed with the ascending ratio of organic modifiers to get the best possible solvent mixer, as well as the physicochemical conditions of the mixers were observed in ambient $\left(25^{\circ} \mathrm{C}\right)$ and cool $\left(2-8^{\circ} \mathrm{C}\right)$ temperature.

Reverse phase columns of $\mathrm{C}_{8}$ and $\mathrm{C}_{18}$ both were used to separate ESP and NAP. But better separation and the sharp peak were found with $\mathrm{C}_{18}$. Column length of $250 \mathrm{~mm}$ was chosen for better separation between ESP and NAP. The flow rate of $0.5-1.5 \mathrm{ml} / \mathrm{min}$ was studied with a different combination of $\mathrm{pH}$ mobile phases to obtain an optimum retention time not compromising on the resolution. The chromatographic condition was optimized using the DoE tools from Minitab 17 Software. During the experiment, a range of factors has been identified as input variables. However, potential four factors wavelength (WL), $\mathrm{pH}$, organic ratio, flow have been provided as input variables in Minitab Software as they play a significant role in the responses. Most of the output responses showed minor variation depending on the chosen factor except Retention Time (RT) and Tailing Factor (TF) that appeared to be convenient parameters for this study. A parallel study on Esomeprazole has been revealed, tailing factor seems to be approximately constant for any range of values of input parameters. Besides, the resolution is not considered as a variable response as the minimum value obtained from the experiment was always higher than the desired value when methanol has been used as an organic modifier. Thus, optimization was not necessary for resolution as a response parameter.

At this optimization stage, forced degradation studies were also performed, in which a specific stability-indicating assay method was established.

\section{Method validation \\ System suitability}

Table 3 summarizes the test results of the system suitability study. All the chromatograms (Fig. 5) results showed system suitability parameters for analysis.

\section{Specificity}

The method was specific since the diluents and excipients in the formulation did not interfere with the estimation of ESP and NAP. The results acquired from the peak purity tool confirmed that the active components' peak response was pure proving no other substances in the same retention time (Fig. 6).
Table 3 Results of system suitability

\begin{tabular}{|c|c|c|c|}
\hline \multirow[t]{2}{*}{ Parameters } & \multicolumn{2}{|l|}{ Results } & \multirow[t]{2}{*}{ Recommendation } \\
\hline & Naproxen & Esomeprazole & \\
\hline $\begin{array}{l}\text { Theoretical plates } \\
(\mathrm{N})\end{array}$ & 6251 & 6400 & Mean $(n=6)>2000$ \\
\hline Capacity factor (K') & 1.85 & 3.23 & $K^{\prime}>2.0$ \\
\hline Resolution (Rs) & - & 8.25 & $\begin{array}{l}>2 \text { between NAP } \\
\text { and ESP }\end{array}$ \\
\hline Tailing factor (TF) & 1.06 & 1.00 & Mean $(n=6) \leq 2$ \\
\hline Repeatability & 0.05 & 0.21 & $\% \operatorname{RSD}(n=6)<2.00$ \\
\hline Retention time (RT) & 0.27 & 0.20 & $\% \operatorname{RSD}(n=6)<2.00$ \\
\hline
\end{tabular}

System suitability has been assessed by six replicate injections

\section{Forced degradation study}

In forced degradation, it was observed that ESP is susceptible to degradation in acid and oxidative stress conditions, whereas NAP is found to be stable under all stress conditions. In every case, the peak purity was $99.96-$ $100.00 \%$. The results acquired from the peak purity tool confirmed that the active components' peak response was pure proving no other substances in the same retention time (Fig. 7).

\section{Accuracy with placebo}

The results were expressed as percent recoveries of the components in the samples. Recovery data are given in Tables 4 and 5. The regression equation for ESP and NAP was found $y=1.012 x-0.095\left(R^{2}=0.999\right)$ and $y=1.014 . x-2.942\left(R^{2}=0.999\right)$ respectively. The overall results of percent recoveries of drug-matrix solutions are indicating good accuracy of the proposed method.

\section{Linearity}

The regression equation from linearity study for ESP and NAP was $y=8956 x+15.3\left(R^{2}=0.999\right)$ and $y=5634 . x+110\left(R^{2}=0.999\right)$ respectively. The data collected from regression analysis indicates the high degree of correlation between peak areas and concentrations of the analyte within a given range which are $8-12 \mu \mathrm{g} / \mathrm{ml}$ for ESP and 200-300 $\mu \mathrm{g} / \mathrm{ml}$ for NAP.

\section{Precision}

Statistical analysis for repeatability, intermediate precision, and reproducibility of ESP and NAP are given in Tables 6 and 7. The values of \%RSD were found very well and within the $2 \%$ limit, indicating that the current method is precise and reproducible.

\section{Solution stability}

In the solution stability study, the peak area of ESP standard and assay sample solutions decreased significantly at 


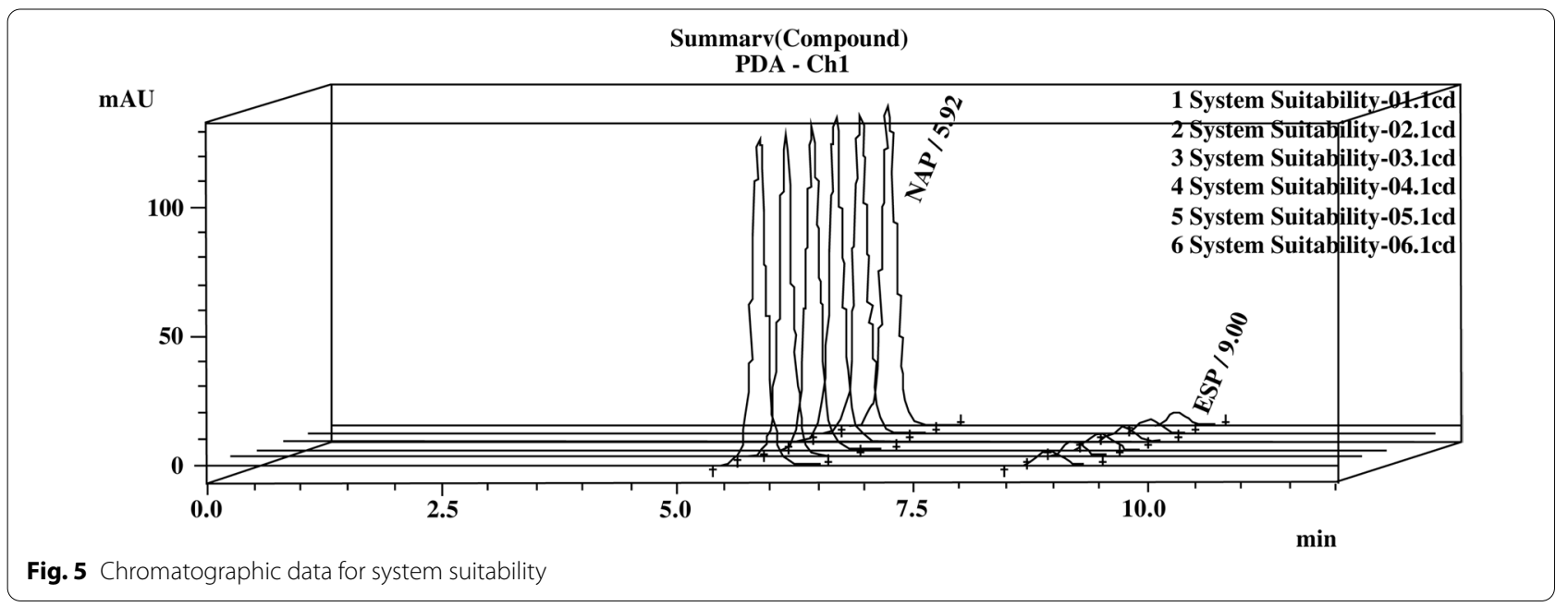

$36 \mathrm{~h}$ which is more than $2.0 \%$ from the initial. This suggests that sample solutions were stable for $24 \mathrm{~h}$, which was sufficient to complete the analytical procedure, details presented in Table 8 .

\section{Robustness}

Robustness results obtained are presented in Table 9, indicating that the \% RSD of retention time and peak area within the $2 \%$ limit of these parameters. Therefore, it can declare that the method is robust.

\section{Sensitivity}

The DL and QL by the proposed method were found for ESP that was $0.19 \mu \mathrm{g} / \mathrm{ml}$ and $0.63 \mu \mathrm{g} / \mathrm{ml}$, respectively.

\section{Application of the method in marketed samples}

The proposed validated method was successfully applied to determine the assay of commercially available samples (three generic brands) containing $20 \mathrm{mg}$ of ESP and $500 \mathrm{mg}$ of NAP the results are summarized in Table 10.

\section{Discussion}

The literature review data clarify that there are no reported methods available for simultaneous estimation of ESP and NAP in a modified bi-layer tablet dosage form [18-44]. The proposed studies include the development of a stability-indicating RP-HPLC method with its succeeding validation for estimation of ESP and NAP simultaneously by applying an appropriate sample preparation process to avoid degradation of acid-labile ESP in presence of acidic NAP. The purpose included establishing a method capable of separating and evaluating ESP and NAP efficiently in the shortest feasible run time with reasonable accuracy and reliability.
Mobile phase optimization study shows that with increasing $\mathrm{pH}$ of the mobile phase the solutions become opaque in ambient condition and few of them formed crystal after refrigeration. The mobile phase of $\mathrm{MeOH}$ : Buffer in the ratio of $40: 60 \% \mathrm{v} / \mathrm{v}$ and $50: 50 \% \mathrm{v} / \mathrm{v}$ was selected for further study. Initial mobile phase as $\mathrm{MeOH}$ : Buffer in the ratio of $40: 60 \% \mathrm{v} / \mathrm{v}$ at $1.5 \mathrm{~mL} / \mathrm{min}$ flow rate was applied, however, the retention time was found 13-14 min for NAP and 23-24 min for ESP which was a long run time. Phosphate buffer of varied, $\mathrm{pH}$ was tried with $\mathrm{ACN}$ in a different ratio where the peaks found sharp having good symmetry, but the resolution between ESP and NAP was observed very low. On contrary, mobile phase buffer combined with $\mathrm{MeOH}$ gives better resolution between ESP and NAP since the elution rate of API is higher in ACN than $\mathrm{MeOH}$. To obtain a better resolution, $\mathrm{ACN}$ was avoided in this study.

Figure 8a provides a graphical illustration of the variation of tailing factors depending on wavelength, $\mathrm{pH}$, flow rate, and organic ratio. A linear increase in tailing factor can be seen for the wavelength of and $\mathrm{pH}$ factors. However, the gradient for $\mathrm{pH}$ is much higher than that, obtained for wavelength. On the other hand, a consistent reduction in tailing has been recorded as the flow rate and organic ratio have been increased. The data was collected with flow rate and organic ratio ranges between $0.5-1.5 \%$ and $40-50 \%$, respectively. The gradient obtained for the tailing factor with respect to the organic ratio appears to be much lower than that of the flow rate. Figure $8 \mathrm{~b}, \mathrm{c}$ provide a graphical representation of the data collected from a study to investigate the variation of retention time of NAP and ESP respectively corresponding to a range of values of few parameters. The data indicates retention time remains constant for any wavelength and $\mathrm{pH}$ value within the range of 254-300 


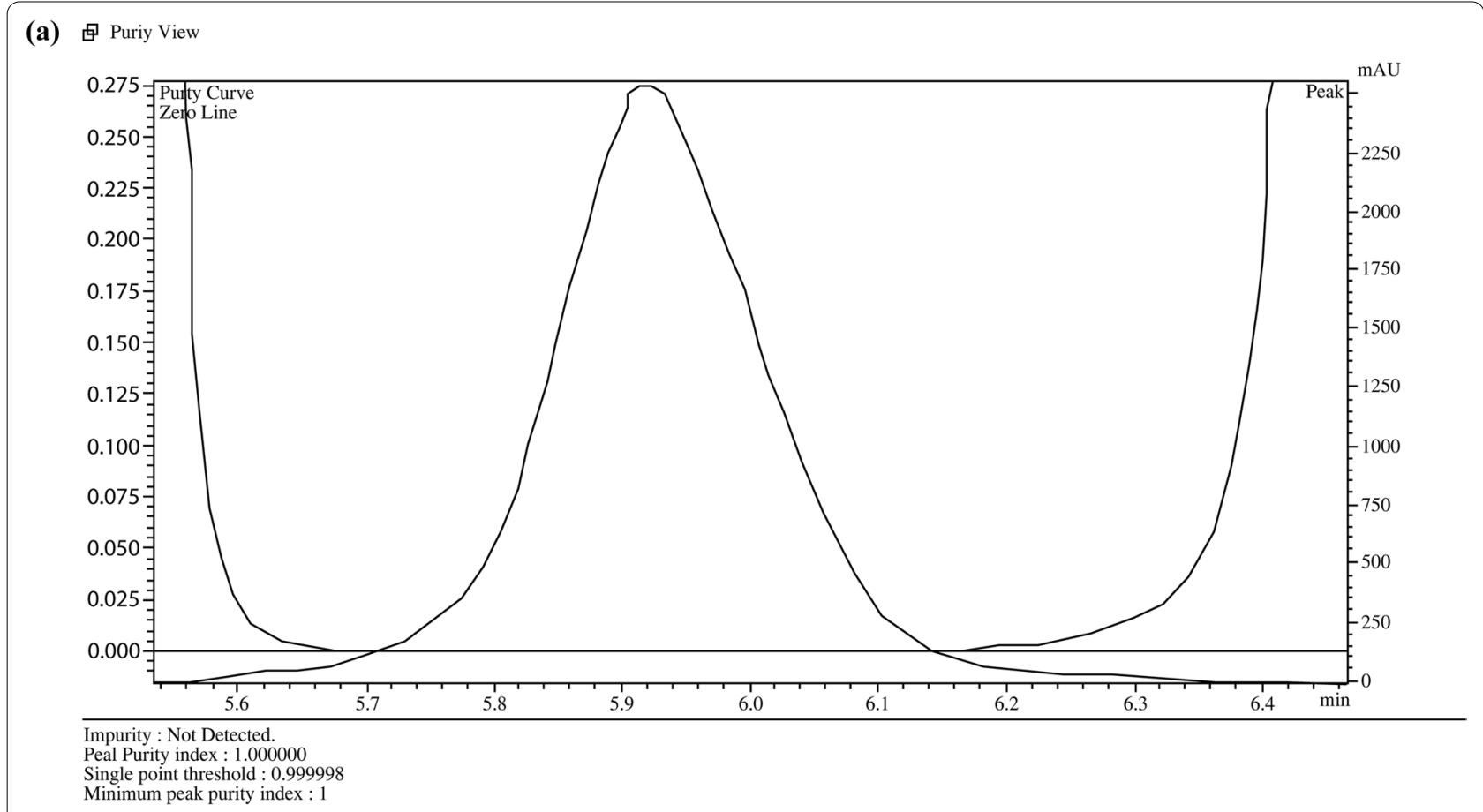

(b) 吕 Purity View

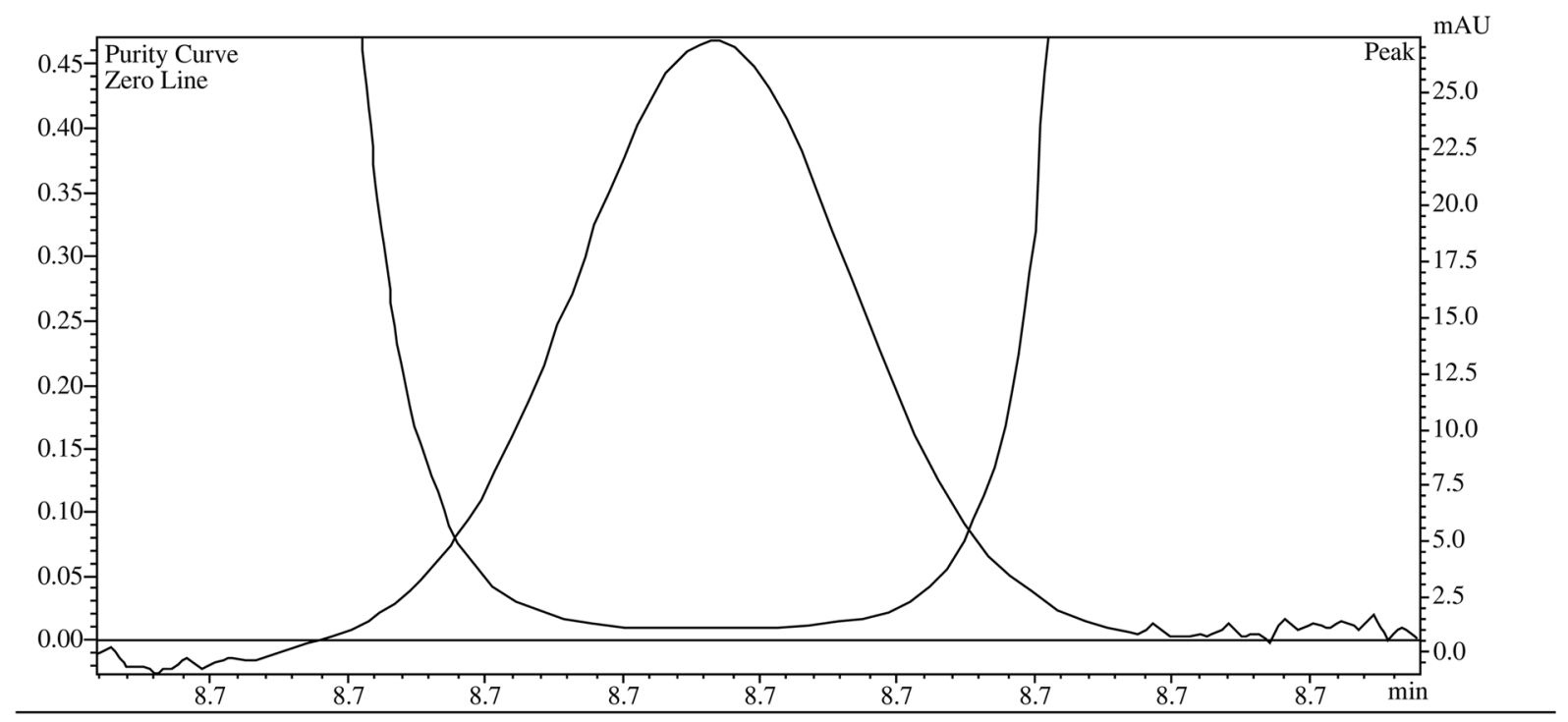

Impurity : Not Detected.

Peak purity index : 0.999718

Single point threshold : 0.990223

Minimum peak purity index : 9495

Fig. 6 Peak purity of assay sample, a peak purity curve for NAP and $\mathbf{b}$ peak purity curve for ESP

and 6-7, respectively. However, a dramatic decrease in retention time has been recorded for both organic ratio and flow rate.

The analytical quality-by-design approach was successfully implemented to develop the RP-HPLC method for simultaneous estimation of ESP and NAP in a modified bi-layer tablet dosage form which has reduced the risk of failure for the method validation process as well as transfer. The separation was carried out on C18, $250 \times 4.6 \mathrm{~mm}$ ID, and $5 \mu \mathrm{m}$ particle size column, and the injection volume was $10 \mu \mathrm{L}$ using a diode array detector (DAD) to monitor the detection at $280 \mathrm{~nm}$. A forced degradation 


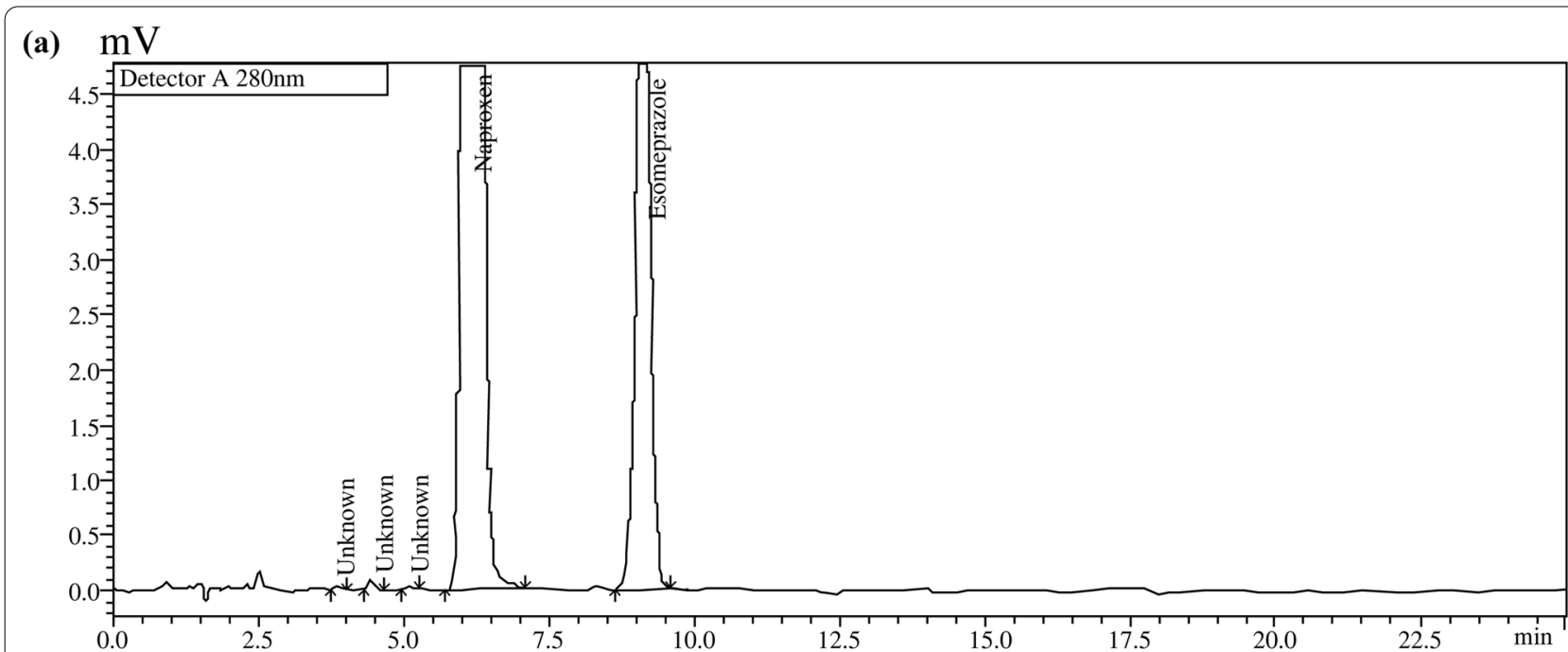

(b) $\mathrm{mV}$

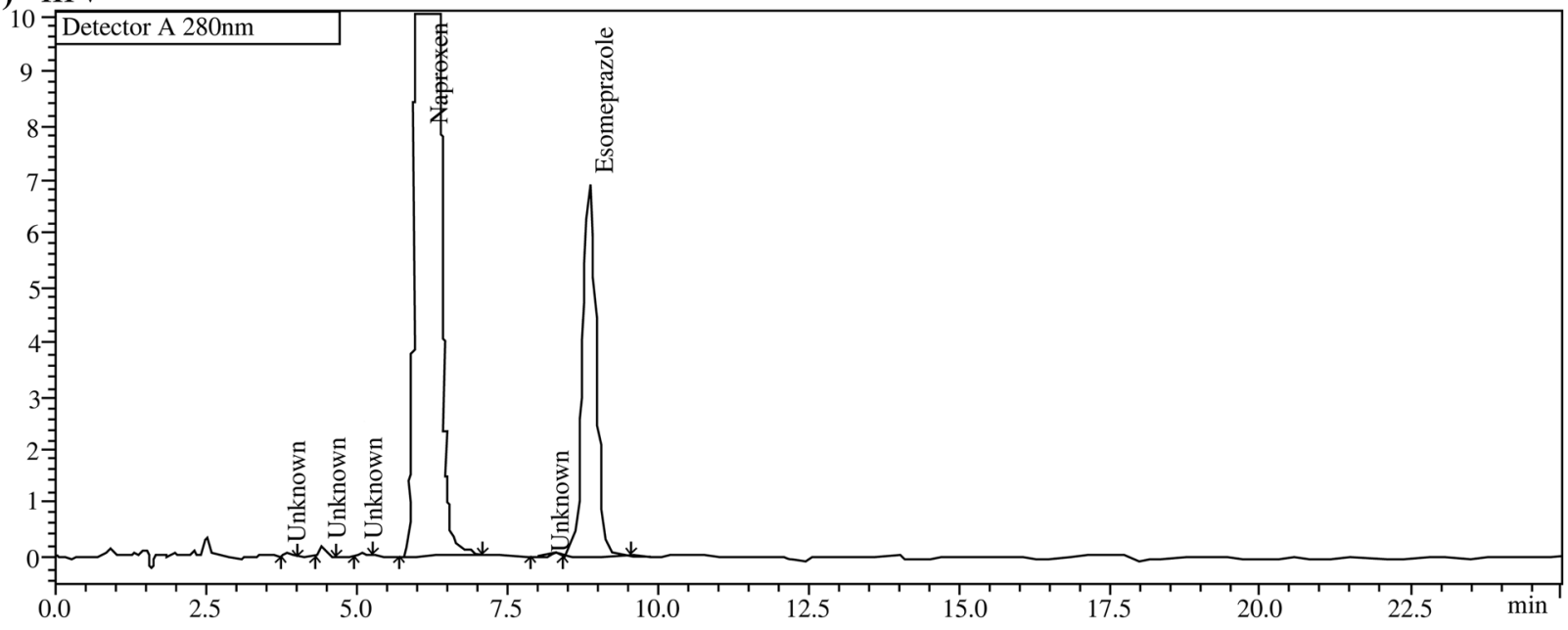

(c) $\mathrm{mV}$

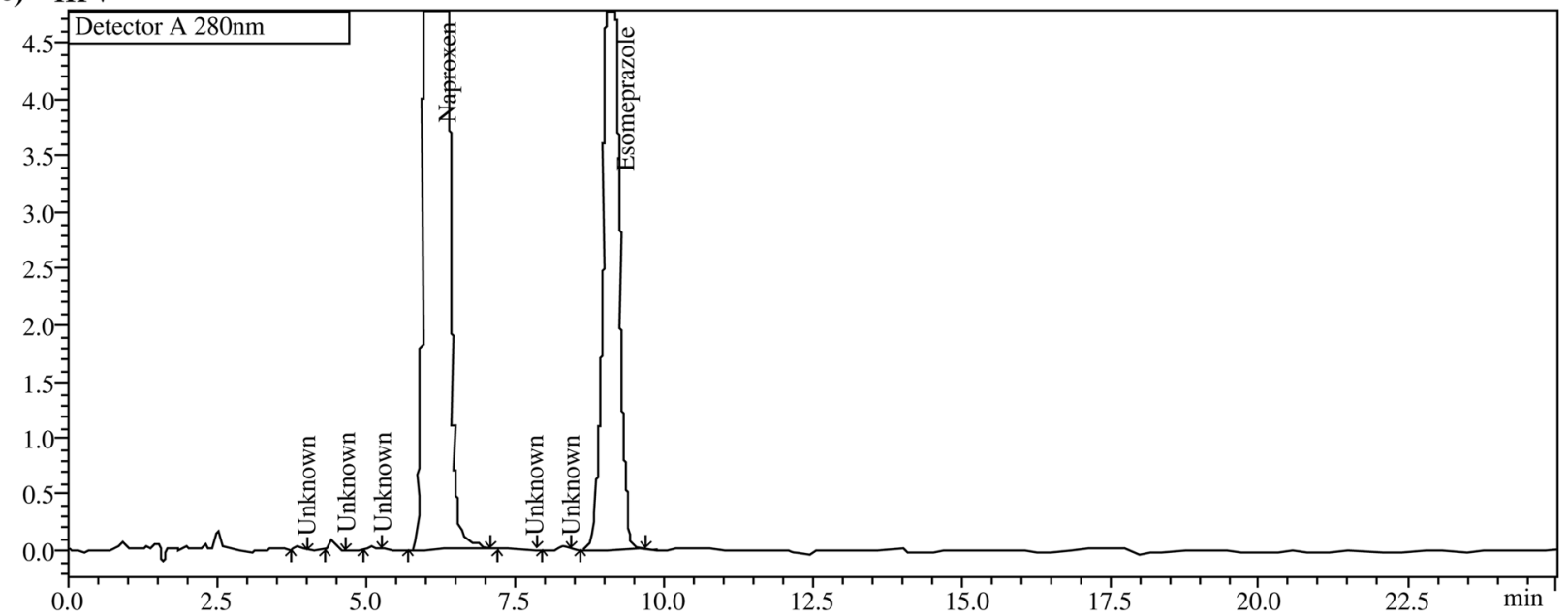

Fig. 7 Representative chromatograms of forced degradation study a API, $0.01 \mathrm{~N} \mathrm{HCl}$ at $40^{\circ} \mathrm{C}, \mathbf{b}$ API with placebo mix at $40{ }^{\circ} \mathrm{C}, 75 \% \mathrm{RH}, \mathbf{c} \mathrm{API}$ with placebo mix at $60^{\circ} \mathrm{C}$ 
Table 4 Data of accuracy with placebo for recovery analysis for NAP

\begin{tabular}{|c|c|c|c|c|c|c|}
\hline \multicolumn{2}{|c|}{$\begin{array}{l}\text { The concentration of sample with } \\
\text { placebo } \mu \mathrm{g} / \mathrm{ml}\end{array}$} & \multicolumn{2}{|c|}{ Peak area of NAP } & \multicolumn{2}{|c|}{ Recovered Concentration $\mu \mathrm{g} / \mathrm{ml}$} & \multirow[t]{2}{*}{$\%$ Recovery } \\
\hline Individual & Average & Sample & Standard & Individual & Average & \\
\hline 200.11 & \multirow[t]{3}{*}{200.16} & $1,124,221$ & \multirow{9}{*}{$\begin{array}{l}1,407,448 \\
(250.40 \mu \mathrm{g} / \mathrm{ml})\end{array}$} & 200.01 & \multirow[t]{3}{*}{200.35} & 99.95 \\
\hline 200.21 & & $1,128,894$ & & 200.84 & & 100.32 \\
\hline 200.15 & & $1,125,319$ & & 200.21 & & 100.03 \\
\hline 249.90 & \multirow[t]{3}{*}{249.96} & $1,404,567$ & & 249.89 & \multirow[t]{3}{*}{249.92} & 99.99 \\
\hline 250.03 & & $1,404,970$ & & 249.96 & & 99.97 \\
\hline 249.95 & & $1,404,707$ & & 249.91 & & 99.98 \\
\hline 300.51 & \multirow[t]{3}{*}{300.33} & $1,698,949$ & & 302.26 & \multirow[t]{3}{*}{301.94} & 100.58 \\
\hline 300.34 & & $1,698,704$ & & 302.22 & & 100.63 \\
\hline 300.15 & & $1,693,779$ & & 301.34 & & 100.40 \\
\hline
\end{tabular}

Table 5 Data of accuracy with placebo for recovery analysis for ESP

\begin{tabular}{|c|c|c|c|c|c|c|}
\hline \multicolumn{2}{|c|}{$\begin{array}{l}\text { The concentration of sample with } \\
\text { placebo } \mu \mathrm{g} / \mathrm{ml}\end{array}$} & \multicolumn{2}{|c|}{ Peak area of ESP } & \multicolumn{2}{|c|}{ Recovered concentration $\mu \mathrm{g} / \mathrm{ml}$} & \multirow[t]{2}{*}{$\%$ Recovery } \\
\hline Individual & Average & Sample & Standard & Individual & Average & \\
\hline 8.10 & \multirow[t]{3}{*}{8.11} & 72,099 & \multirow{9}{*}{$\begin{array}{l}90,584 \\
(10.20 \mu \mathrm{g} / \mathrm{ml})\end{array}$} & 8.12 & 8.13 & 100.23 \\
\hline 8.18 & & 72,448 & & 8.16 & & 99.73 \\
\hline 8.05 & & 72,026 & & 8.11 & & 100.75 \\
\hline 10.05 & \multirow[t]{3}{*}{10.08} & 89,630 & & 10.09 & 10.10 & 100.42 \\
\hline 10.11 & & 89,695 & & 10.10 & & 99.90 \\
\hline 10.08 & & 89,654 & & 10.10 & & 100.15 \\
\hline 12.20 & \multirow[t]{3}{*}{12.19} & 109,138 & & 12.29 & 12.26 & 100.73 \\
\hline 12.14 & & 108,515 & & 12.22 & & 100.65 \\
\hline 12.22 & & 108,914 & & 12.26 & & 100.36 \\
\hline
\end{tabular}

Table 6 Repeatability and intermediate precision of ESP and NAP

\begin{tabular}{|c|c|c|c|c|c|c|}
\hline & \multicolumn{6}{|c|}{ Mean value of three replicate injections of NAP } \\
\hline & \multicolumn{2}{|c|}{$80 \%$ Concentration } & \multicolumn{2}{|c|}{$100 \%$ Concentration } & \multicolumn{2}{|c|}{$120 \%$ Concentration } \\
\hline & RT & Peak area & RT & Peak area & RT & Peak area \\
\hline Intra-day precision & 5.95 & $1,124,957$ & 5.93 & $1,401,766$ & 5.94 & $1,691,046$ \\
\hline Inter-day precision & 5.97 & $1,124,636$ & 5.96 & $1,401,854$ & 5.93 & $1,691,849$ \\
\hline \multirow[t]{4}{*}{$\%$ RSD } & 0.02 & 0.02 & 0.00 & 0.00 & 0.03 & 0.03 \\
\hline & \multicolumn{6}{|c|}{ Mean value of three replicate injections of ESP } \\
\hline & \multicolumn{2}{|c|}{$80 \%$ Concentration } & \multicolumn{2}{|c|}{$100 \%$ Concentration } & \multicolumn{2}{|c|}{$120 \%$ Concentration } \\
\hline & RT & Peak area & RT & Peak area & $\mathrm{RT}$ & Peak area \\
\hline Intra-day precision & 9.04 & 72,647 & 9.00 & 89,263 & 9.04 & 105,819 \\
\hline Inter-day precision & 9.04 & 72,379 & 9.02 & 89,304 & 9.05 & 106,398 \\
\hline$\% \mathrm{RSD}$ & 0.03 & 0.08 & 0.21 & 0.03 & 0.10 & 0.39 \\
\hline
\end{tabular}

Repeatability and Intermediate Precision have been assessed using 3 concentration/3 replicates each 
Table 7 Reproducibility of ESP and NAP

\begin{tabular}{|c|c|c|c|c|}
\hline \multirow[t]{2}{*}{ Reproducibility } & \multicolumn{2}{|c|}{$\begin{array}{l}\text { Six replicate injections } \\
\text { of NAP }\end{array}$} & \multicolumn{2}{|c|}{$\begin{array}{l}\text { Six replicate } \\
\text { injections of ESP }\end{array}$} \\
\hline & RT & Peak area & RT & Peak area \\
\hline Mean & 5.96 & $1,405,485$ & 9.05 & 89,244 \\
\hline$\%$ RSD & 0.31 & 0.06 & 0.32 & 0.15 \\
\hline
\end{tabular}

Mean and RSD of six replicates

study was performed by applying various stress conditions to the sample to evaluate the peak purity and stability-indicating nature of the developed method. During the forced degradation study, we observed that degradation of ESP was more significant at acid and oxidative conditions. The developed method was validated as per $\mathrm{ICH}$ guidelines, the validated method was found to be linear, precise, accurate, specific, robust, and timesaving with the minimum usage of organic solvents.

\section{Conclusions}

The developed RP-HPLC method for the simultaneous estimation of ESP and NAP is simple, precise, accurate, reproducible, and highly sensitive. The reproducibility of this method has been observed by using different HPLC instruments and other laboratories. Hence, this method can be routinely used for the simultaneous estimation of ESP and NAP in modified-release tablet form of pharmaceutical formulations.

Table 8 Data for solution stability analysis

\begin{tabular}{|c|c|c|c|c|c|c|c|c|}
\hline \multirow{3}{*}{$\begin{array}{l}\text { Time } \\
\text { interval (h) }\end{array}$} & \multicolumn{4}{|c|}{ ESP solution stability } & \multicolumn{4}{|c|}{ NAP solution stability } \\
\hline & \multicolumn{2}{|l|}{ Standard } & \multicolumn{2}{|l|}{ Sample } & \multirow{2}{*}{$\begin{array}{l}\text { Standard } \\
\text { Peak area }\end{array}$} & \multirow[b]{2}{*}{$\%$ Difference } & \multirow{2}{*}{$\begin{array}{l}\text { Sample } \\
\text { Peak area }\end{array}$} & \multirow[b]{2}{*}{$\%$ Difference } \\
\hline & Peak area & \% Difference & Peak area & $\%$ Difference & & & & \\
\hline 0 & 89,641 & - & 89,657 & - & $1,404,970$ & - & $1,404,785$ & - \\
\hline 12 & 89,568 & -0.08 & 89,658 & 0.00 & $1,404,785$ & -0.01 & $1,404,797$ & 0.00 \\
\hline 24 & 88,782 & -0.88 & 89,609 & -0.05 & $1,404,112$ & -0.05 & $1,404,757$ & 0.00 \\
\hline 36 & 86,654 & -2.40 & 86,152 & -3.86 & $1,403,866$ & -0.02 & $1,404,518$ & -0.02 \\
\hline
\end{tabular}

Table 9 Effects of robustness study of ESP and NAP under different altered conditions

\begin{tabular}{|c|c|c|c|c|c|c|}
\hline Parameter & Theoretical variance & Actual variance & $\begin{array}{l}\% \text { RSD of RT } \\
\text { for NAP }\end{array}$ & $\begin{array}{l}\% \text { RSD of peak } \\
\text { area for NAP }\end{array}$ & $\begin{array}{l}\text { \% RSD of RT } \\
\text { for ESP }\end{array}$ & $\begin{array}{l}\% \text { RSD of peak } \\
\text { area for ESP }\end{array}$ \\
\hline \multirow[t]{2}{*}{ Elution ratio of organic } & \multirow[t]{2}{*}{ $\pm 2.0 \%$ of the set ratio } & $48 \% \mathrm{v} / \mathrm{V}$ & 0.20 & 0.13 & 0.13 & 0.69 \\
\hline & & $52 \% \mathrm{v} / \mathrm{v}$ & 0.45 & 0.14 & 0.26 & 0.75 \\
\hline \multirow[t]{2}{*}{ Column oven temperature } & \multirow[t]{2}{*}{ $\pm 2^{\circ} \mathrm{C}$ of the set temperature } & $28^{\circ} \mathrm{C}$ & 0.11 & 0.06 & 0.08 & 0.64 \\
\hline & & $32^{\circ} \mathrm{C}$ & 0.25 & 0.21 & 0.18 & 0.31 \\
\hline \multirow[t]{2}{*}{ Flow rate } & \multirow[t]{2}{*}{ $\pm 10 \%$ of the set flow } & $1.35 \mathrm{ml} / \mathrm{min}$ & 0.28 & 0.06 & 0.28 & 0.71 \\
\hline & & $1.65 \mathrm{ml} / \mathrm{min}$ & 1.33 & 0.80 & 1.25 & 1.34 \\
\hline
\end{tabular}

Table 10 Determination of ESP and NAP in marketed samples

\begin{tabular}{|c|c|c|c|c|c|c|}
\hline \multirow[t]{2}{*}{ Generic brands } & \multicolumn{3}{|l|}{ ESP } & \multicolumn{3}{|l|}{ NAP } \\
\hline & Label amount (mg) & $\begin{array}{l}\text { Observed amount } \\
\text { (mg) }\end{array}$ & Assay (\%) & Label amount (mg) & $\begin{array}{l}\text { Observed amount } \\
(\mathrm{mg})\end{array}$ & Assay (\%) \\
\hline B-1 & 20.00 & 21.71 & 108.55 & 500.00 & 504.70 & 100.94 \\
\hline$B-2$ & 20.00 & 19.82 & 99.08 & 500.00 & 514.95 & 102.99 \\
\hline B-3 & 20.00 & 21.50 & 107.49 & 500.00 & 518.57 & 103.71 \\
\hline
\end{tabular}


TF (NAP) vs. Factors

Data Means

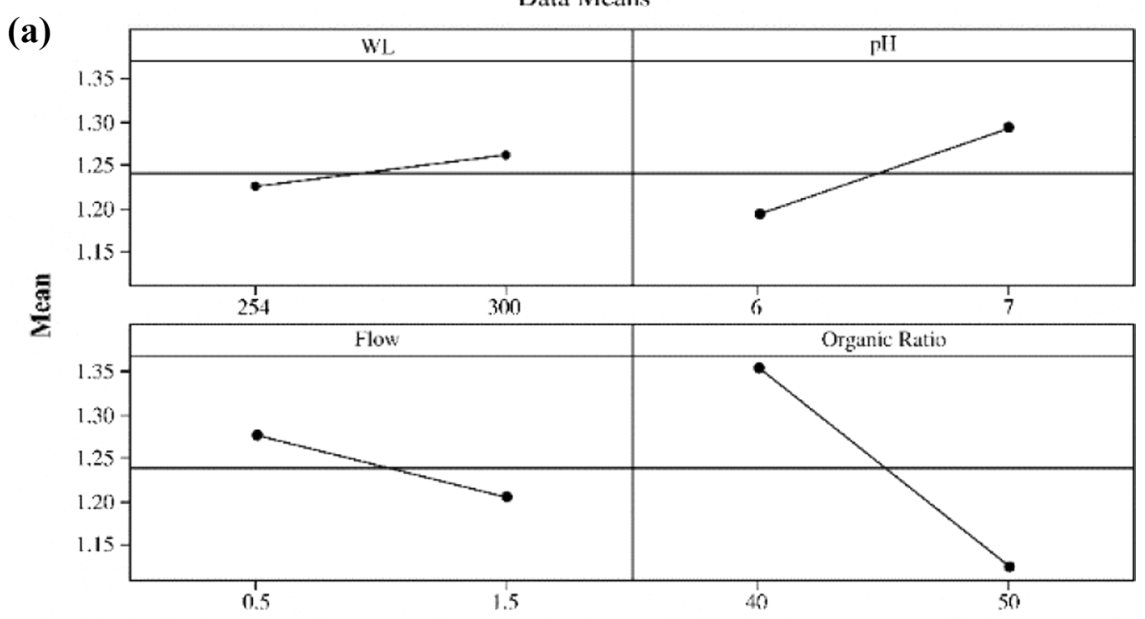

RT (NAP) vs. Factors

(b)

Data Means

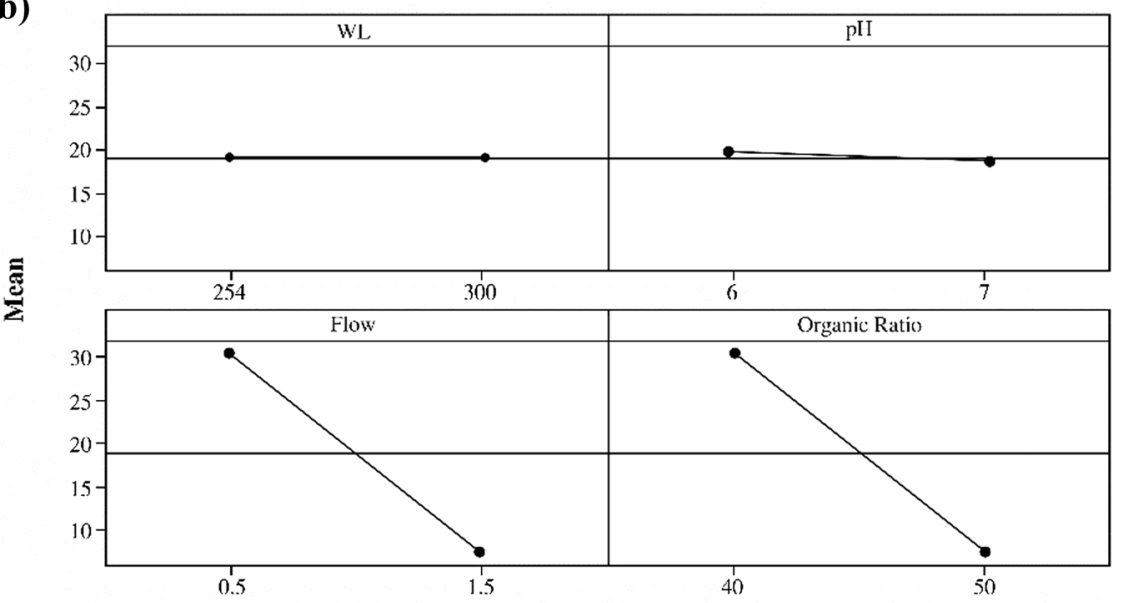

RT (ESP) vs. Factors

(c)

Data Means

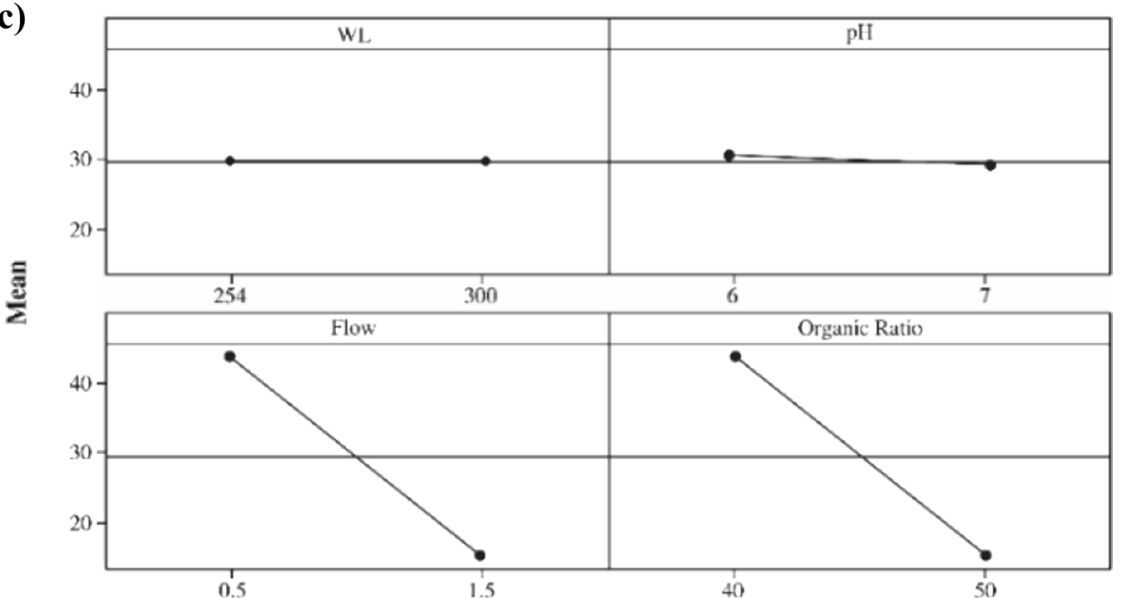

Fig. 8 Main effect plot of responses versus factors 


\section{Abbreviations}

RP-HPLC: Reversed-phase high-pressure liquid chromatography; AQbD: Analytical Quality by Design; PDA: Photo Diode Array; RSD: Relative standard deviation; $R^{2}$ : Coefficient of correlation; USFDA: US Food and Drug Administration; ICH: International Council for Harmonisation; ATP: Analytical Target Profile; DoE: Design of Experiments; QRA: Quality Risk Assessment; APIs: Active Pharmaceutical Ingredients.

\section{Acknowledgements}

The authors are thankful to ACI Limited., Bangladesh, for providing gift samples and to the Department of Pharmacy, University of Asia Pacific for providing facilities to carry out the research work.

\section{Authors' contributions}

$\mathrm{KF}, \mathrm{SN}$, and Al contributed equally for preceding this research. Concept and guidance were from SN and $\mathrm{Al}$, and the final manuscript was prepared and checked by KF and SN. We declare that all authors have read and approved the final manuscript.

\section{Funding}

The present research was not funded by any funding source.

\section{Availability of data and materials}

All data and materials are available upon request.

\section{Declarations}

\section{Ethics approval and consent to participate}

Not applicable.

\section{Consent for publication}

Not applicable.

\section{Competing interests}

The authors declare that they have no competing interests.

\section{Author details}

${ }^{1}$ Department of Pharmacy, University of Asia Pacific, Dhaka 1205, Bangladesh. ${ }^{2}$ Quality Assurance Department, ACI HealthCare Limited, Treepordi, Sonargaon, Narayanganj 1440, Bangladesh.

Received: 18 July 2021 Accepted: 22 December 2021

Published online: 07 January 2022

\section{References}

1. Sangshetti JN, Deshpande M, Zaheer Z, Shinde DB, Arote R (2017) Quality by design approach: regulatory need. Arab J Chem 10:S3412-\$3425. https://doi.org/10.1016/j.arabjc.2014.01.025

2. Yu LX, Amidon G, Khan MA, Hoag SW, Polli J, Raju GK, Woodcock J (2014) Understanding pharmaceutical quality by design. AAPS J 16:771-783. https://doi.org/10.1208/s12248-014-9598-3

3. Abboud L, Hensley S (2003) New prescription for drug makers: update the plants. Wall Str J Online

4. SkyMark (2017) Joseph M. Juran: a quality life. http://www.skymark.com/ resources/leaders/juran.asp. Accessed 18 May 2021

5. Juran JM (1993) Juran's quality handbook

6. Juran JM (1992) Juran on quality by design : the new steps for planning quality into goods and services LK. https://ulaval.on.worldcat.org/oclc/ 300928871

7. Early JF (2013) Quality by design, Part 1 Preventing quality failures at their source. In: Quality digest. https://www.qualitydigest.com/inside/qualityinsider-article/quality-design-part-1.html\#. Accessed 18 May

8. ICH Expert Working Group (2009) Ich Harmonised tripartite Guideline. Pharmaceutical development Q8 (R2), vol 8, pp 1-28

9. Tome T, Žigart N, Časar Z, Obreza A (2019) Development and optimization of liquid chromatography analytical methods by using AQbD principles: overview and recent advances. Org Process Res Dev 23:1784-1802
10. Peraman R, Bhadraya K, Padmanabha Reddy Y (2015) Analytical quality by design: a tool for regulatory flexibility and robust analytics. Int J Anal Chem. https://doi.org/10.1155/2015/868727

11. Dispas A, Avohou HT, Lebrun P, Hubert P, Hubert C (2018) 'Quality by Design' approach for the analysis of impurities in pharmaceutical drug products and drug substances. TrAC Trends Anal Chem 101:24-33

12. Peraman R, Bhadraya K, Reddy YP, Reddy CS, Lokesh T (2015) Analytical quality by design approach in RP-HPLC method development for the assay of etofenamate in dosage forms. Indian J Pharm Sci 77:751-757. https://doi.org/10.4103/0250-474X.174971

13. Beg S, Sharma G, Katare OP, Lohan S, Singh B (2015) Development and validation of a stability-indicating liquid chromatographic method for estimating olmesartan medoxomil using quality by design. J Chromatogr Sci 53:1048-1059. https://doi.org/10.1093/chromsci/bmu165

14. Manoel JW, Primieri GB, Bueno LM, Wingert NR, Volpato NM, Garcia CV, Scherman Schapoval EE, Steppe M (2020) The application of quality by design in the development of the liquid chromatography method to determine empagliflozin in the presence of its organic impurities. RSC Adv 10:7313-7320. https://doi.org/10.1039/c9ra08442h

15. Andersson T, Hassan-Alin M, Hasselgren G, Röhss K, Weidolf L (2001) Pharmacokinetic studies with esomeprazole, the (S)-isomer of omeprazole. Clin Pharmacokinet 40:411-426

16. Scott LJ, Dunn CJ, Mallarkey G, Sharpe M (2002) Esomeprazole: a review of its use in the management of acid-related disorders. Drugs 62:1503-1538

17. Silverstein FE, Faich G, Goldstein JL, Simon LS, Pincus T, Whelton A, Makuch R, Eisen G, Agrawal NM, Stenson WF, Burr AM, Zhao WW, Kent JD, Lefkowith JB, Verburg KM, Geis GS (2000) Gastrointestinal toxicity with Celecoxib vs nonsteroidal anti-inflammatory drugs for osteoarthritis and reumatoid arthritis: The CLASS study: a randomized controlled trial. J Am Med Assoc 284:1247-1255. https://doi.org/10.1001/jama.284.10.1247

18. Shetty R, Subramanian G, Ranjith Kumar A, Pandey S, Udupa N (2005) Estimation of esomeprazole in human plasma by reverse phase high performance liquid chromatography. Indian Drugs 42:158-161

19. Önal A, Öztunç A (2006) Development and validation of high-performance liquid chromatographic method for the determination of esomeprazole in tablets. J Food Drug Anal 14:12-18. https://doi.org/10.38212/ 2224-6614.2503

20. Hultman I, Stenhoff H, Liljeblad M (2007) Determination of esomeprazole and its two main metabolites in human, rat and dog plasma by liquid chromatography with tandem mass spectrometry. J Chromatogr B Anal Technol Biomed Life Sci 848:317-322. https://doi.org/10.1016/j.jchromb. 2006.10.074

21. Patel BH, Suhagia BN, Patel MM, Patel JR (2007) Determination of pantoprazole, rabeprazole, esomeprazole, domperidone and itopride in pharmaceutical products by reversed phase liquid chromatography using single mobile phase. Chromatographia 65:743-748. https://doi.org/ 10.1365/s10337-007-0220-z

22. Prabu S, Shirwaikar A, Shirwaikar A, Kumar C, Joseph A, Kumar R (2008) Simultaneous estimation of esomeprazole and domperidone by UV spectrophotometric method. Indian J Pharm Sci 70:128-131. https://doi. org/10.4103/0250-474X.40351

23. Magesh AR, Vijayalakshmi R, Satyavati D, Sravanthi Devi G, Dhanaraju MD (2010) Validated spectrophotometric estimation of esomeprazole using hydrotrophic solubilisation technique. Orient J Chem 26:1191-1193

24. Zanitti L, Ferretti R, Gallinella B, La Torre F, Sanna ML, Mosca A, Cirilli R (2010) Direct HPLC enantioseparation of omeprazole and its chiral impurities: application to the determination of enantiomeric purity of esomeprazole magnesium trihydrate. J Pharm Biomed Anal 52:665-671. https://doi.org/10.1016/j.jpba.2010.02.021

25. Mortensen RW, Corcoran O, Cornett C, Sidelmann UG, Troke J, Lindon JC, Nicholson JK, Hansen SH (2001) LC-1H NMR used for determination of the elution order of S-naproxen glucuronide isomers in two isocratic reversed-phase LC-systems. J Pharm Biomed Anal 24:477-485. https:// doi.org/10.1016/S0731-7085(00)00453-2

26. Sidelmann UG, Bjornsdottir I, Shockcor JP, Hansen SH, Lindon JC, Nicholson JK (2001) Directly coupled HPLC-NMR and HPLC-MS approaches for the rapid characterisation of drug metabolites in urine: application to the human metabolism of naproxen. J Pharm Biomed Anal 24:569-579. https://doi.org/10.1016/S0731-7085(00)00482-9 
27. Tong JH, Rodriguez L, Corporation B (2001) High-performance liquid chromatographic method development and validation for the simultaneous quantitation of naproxen sodium and pseudoephedrine hydrochloride impurities. J Chromatogr Sci 39:81-86. https://doi.org/10.1093/ chromsci/39.3.81

28. Damiani PC, Borraccetti MD, Olivieri AC (2002) Direct and simultaneous spectrofluorometric determination of naproxen and salicylate in human serum assisted by chemometric analysis. Anal Chim Acta 471:87-96. https://doi.org/10.1016/S0003-2670(02)00925-X

29. Damiani P, Bearzotti M, Cabezón MA (2002) Spectrofluorometric determination of naproxen in tablets. J Pharm Biomed Anal 29:229-238. https:// doi.org/10.1016/S0731-7085(02)00063-8

30. Monser L, Darghouth F (2003) Simultaneous determination of naproxen and related compounds by HPLC using porous graphitic carbon column. J Pharm Biomed Anal 32:1087-1092

31. Tashtoush BM, Al-Taani BM (2003) HPLC determination of naproxen in plasma. Pharmazie 39:624-630. https://doi.org/10.1016/j.jpba.2005.04. 008

32. Sun Y, Takaba K, Kido H, Nakashima MN, Nakashima K (2003) Simultaneous determination of arylpropionic acidic non-steroidal anti-inflammatory drugs in pharmaceutical formulations and human plasma by HPLC with UV detection. J Pharm Biomed Anal 30:1611-1619. https://doi.org/ 10.1016/S0731-7085(02)00549-6

33. Aresta A, Palmisano F, Zambonin CG (2005) Determination of naproxen in human urine by solid-phase microextraction coupled to liquid chromatography. J Pharm Biomed Anal 39:643-647. https://doi.org/10.1016/j. jpba.2005.04.017

34. Zakeri-Milani P, Barzegar-Jalali M, Tajerzadeh H, Azarmi Y, Valizadeh H (2005) Simultaneous determination of naproxen, ketoprofen and phenol red in samples from rat intestinal permeability studies: HPLC method development and validation. J Pharm Biomed Anal 39:624-630. https:// doi.org/10.1016/j.jpba.2005.04.008

35. Dinç E, Özdemir A, Aksoy H, Üstündağ Ö, Baleanud D (2006) Chemometric determination of naproxen sodium and pseudoephedrine hydrochloride in tablets by HPLC. Chem Pharm Bull 54:415-421. https://doi.org/10. 1248/cpb.54.415

36. Phillips TM, Wellner EF (2006) Measurement of naproxen in human plasma by chip-based immunoaffinity capillary electrophoresis. Biomed Chromatogr 20:662-667. https://doi.org/10.1002/bmc.673

37. Hsu YH, Liou YB, Lee JA, Chen CY, Wu AB (2006) Assay of naproxen by high-performance liquid chromatography and identification of its photoproducts by LC-ESI MS. Biomed Chromatogr 20:787-793. https://doi.org/ 10.1002/bmc.598

38. Sun Y, Zhang Z, Xi Z, Shi Z (2009) Determination of naproxen in human urine by high-performance liquid chromatography with direct electrogenerated chemiluminescence detection. Talanta 79:676-680. https:// doi.org/10.1016/j.talanta.2009.04.048

39. Sakaguchi Y, Yoshida H, Hayama T, Yoshitake M, Itoyama M, Todoroki K, Yamaguchi M, Nohta H (2011) Fluorous derivatization and fluorous-phase separation for fluorometric determination of naproxen and felbinac in human plasma. J Pharm Biomed Anal 55:176-180. https://doi.org/10. 1016/j.jpba.2011.01.011

40. Jain DK, Jain N, Charde R, Jain N (2011) The RP-HPLC method for simultaneous estimation of esomeprazole and naproxen in binary combination. Pharm Methods 2:167-172. https://doi.org/10.4103/2229-4708.90356

41. Sudha T, Surendra B, Saravanan S (2014) Development and validation of reverse phase-high performance liquid chromatographic method for simultaneous estimation of naproxen sodium and esomeprazole magnesium trihydrate. Drug Dev Ther 5:109. https://doi.org/10.4103/2394-2002. 139614

42. Gali H, Yerragunta V (2016) Development and validation of RP-HPLC method for simultaneous estimation of Naproxen and Esomeprazole in pharmaceutical dosage form. Asian J Res Chem 9:366

43. Razzaq SN, Ashfaq M, Khan IU, Mariam I (2012) Development and validation of liquid chromatographic method for naproxen and esomeprazole in binary combination. J Chil Chem Soc 57:1456-1459. https://doi.org/10. 4067/S0717-97072012000400024

44. Ashutosh Kumar S, Debnath M, Seshagiri Rao JVLN (2013) Stability indicating RP-HPLC method for the determination of prasugrel in bulk as well as in pharmaceutical formulation. Res J Pharm Technol 6:809-816
45. ICHHT Guideline (2005) Validation of analytical procedures: text and methodology Q2 (R1). IFPMA, Geneva, pp 27463-27467

46. Nawaz MS (2013) Validation and application of a new reversed phase HPLC method for in vitro dissolution studies of rabeprazole sodium in delayed-release tablets. J Anal Methods Chem. https://doi.org/10.1155/ 2013/976034

\section{Publisher's Note}

Springer Nature remains neutral with regard to jurisdictional claims in published maps and institutional affiliations.

\section{Submit your manuscript to a SpringerOpen ${ }^{\circ}$ journal and benefit from:}

- Convenient online submission

- Rigorous peer review

- Open access: articles freely available online

- High visibility within the field

- Retaining the copyright to your article

Submit your next manuscript at $\boldsymbol{\nabla}$ springeropen.com 